\title{
ANALISIS PERILAKU KONSUMEN DALAM PEMBELIAN TERI KRISPI DI KABUPATEN PAMEKASAN MADURA
}

\author{
Consumer Behavior Analysis In Purchase Of Teri Crispy In Pamekasan Madura \\ District
}

Endang Tri Wahyurini

Fakultas Pertanian Agrobisnis Perikanan

Universitas Islam Madura

e-mail: endangtriwahyurinis.pi_rini@yahoo.co.id

\begin{abstract}
ABSTRAK
Teri merupakan salah satu komoditas perikanan yang memiliki banyak manfaat. Secara nutrisi ikan teri merupakan sumber protein yang sangat tinggi. Salah satu olahan teri yang cukup diminati masyarakat atau konsumen adalah teri krispi. Penelitian dilaksanakan dengan tujuan untuk mengetahui karakteristik dan faktor yang mempengaruhi pembelian teri krispi di Kabupaten Pamekasan. Penelitian dilakukan di Pamekasan, Madura pada bulan Oktober 2016. Jumlah responden sebanyak 70 konsumen yang dipilih secara Insidental Sampling. Data dianalisis dengan cara deskriptif dan analisis faktor. Dari hasil penelitian menunjukkan bahwa sebagian besar responden yang melakukan pembelian teri krispi adalah perempuan, berstatus ibu rumah tangga, berumur diatas 35 tahun, pendapatan individu yang diperoleh antara $\mathrm{Rp}$ 1.000.000,00 sampai Rp. 2.500.000,00 per bulan dengan asumsi harga teri krispi dalam kategori terjangkau oleh konsumen. Konsumen membeli atau mengkonsumsi teri krispi bukan sebagai makanan pokok tetapi sebagai kuliner, oleh-oleh, dan makanan camilan. Delapan faktor yang dipertimbangkan responden secara berurutan adalah harga, rasa, kemasan, tampilan penyajian, kepuasan, pendapatan, dan demografi.

(Kata kunci: Perilaku konsumen, Faktor yang dipertimbangkan, Teri krispi)
\end{abstract}

\begin{abstract}
Teri is one of the fishery commodities that have many benefits. Nutritious fish is a very high source of protein. One of the processed anchovies that are of great interest to the public or the consumer is teri krispi. The objective of this research were to analyzed the characteristics and the factors influencing the purchasing of teri krispi in Pamekasan. The research was conducted in Pamekasan, Madura East Java in October 2016. Seventy consumers were chosen as respondents by Incidental Sampling method. Data were analyzed by descriptive and factor analyses. The results showed that most customers were women, the status of housewife, aged over 35 years, and incomes level of IDR 1.000.000,00 into IDR 2.500.000,00 per month. The teri krispi's price was affordable by the consumers. The consumers purchasing patterns showed that the teri krispi was consumed not only as a main meal but also for culinary, and snacks. The eight factors considered by consumers of teri krispi purchasing consecutively were price, taste, packaging, presentation display, satisfaction, income, and demographics. (Key words: Consumer`s behavior, Considerance factor, Teri krispi)
\end{abstract}




\section{PENDAHULUAN}

Salah satu komoditas ekspor yang memiliki potensi besar adalah teri nasi. Pemasaran teri nasi mengalami peningkatan yang cukup tinggi, baik untuk ekspor maupun konsumsi dalam negeri. Ikan teri sejak lama dikenal oleh masyarakat Indonesia sebagai lauk makan sehari-hari karena mudah diperoleh di hampir seluruh kota di Indonesia dan dapat dimasak untuk berbagai menu. Teri sebagai sumber kalsium memiliki keistimewaan dibandingkan dengan ikan lainnya yaitu bentuk tubuhnya yang kecil sehingga mudah dan praktis dikonsumsi oleh semua umur. Ikan teri merupakan sumber kalsium sebagai pencegah pengeroposan tulang yang tahan dan tidak mudah larut dalam air.

Kandungan gizi teri segar meliputi energi 77 kkal; protein 16 gr;lemak 1.0 gr; kalsium $500 \mathrm{mg}$; phosfor $500 \mathrm{mg}$; besi 1.0 mg; VitA RE 47; dan Vit B $0.1 \mathrm{mg}$. Volume ekspor ikan teri Indonesia pada tiap tahunnya mengalami peningkatan. Pada tahun 2005,volume ekspor ikan teri meningkat tajam menjadi 2.443 ton dengan nilai 16.287.284 US\$ dan tahun 2006 meningkat sebesar $5 \%$ menjadi 2.579 ton dengan nilai 16.437.255 US\$. Berdasarkan rekapitulasi dari Departemen Perindustrian pada 2006, proporsi jumlah industri hasil laut terbanyak di Indonesia ada di provinsi Jawa Timur yaitu sebesar 36,73\% (Partiwi, 2007) dan khusus untuk industri teri nasi terdapat 26 perusahaan berlokasi di Jawa Timur.

Kabupaten Pamekasan dikenal sebagai kota yang memiliki hasil tangkapan ikan yang cukup besar. Salah satunya adalah ikan teri. Teri krispi merupakan produk difersifikasi dari ikan teri. Ikan teri segar yang dicampur dengan terigu dan bumbu kemudian dimasak dengan proses tertentu untuk bisa dikonsumsi. Teri krispi sangat populer dan digemari oleh masyarakat. Hampir semua kalangan menyukainya, dengan harga yang bervariasi dan terjangkau oleh konsumen. Dalam Nazarul A(2016) dijelaskan bahwa ikan teri merupakan sumber protein hewani yaitu $16 \%$ kandungan protein yang sangat dibutuhkan oleh tubuh manusia. Salah satu bentuk diversifikasi ikan teri yaitu teri krispi. Teri krispi dapat dikatakan sebagai produk diversifikasi yang baru sehingga banyak digemari oleh para konsumen. Bahan baku teri krispi berasal dari ikan teri segar.

Usaha teri krispi dapat digolongkan sebagai usaha kecil. Parubak et al. (2004) menjelaskan bahwa usaha kecil mempunyai peranan penting dan strategis 
dalam mewujudkan pembangunan nasional. Usaha kecil merupakan usaha yang ditekuni oleh sebagian besar masyarakat dan merupakan usaha yang mampu memperluas lapangan kerja dan memberikan pelayanan yang luas kepada masyarakat. Pemerintah terus berupaya membina kelompok usaha kecil agar menjadi usaha yang semakin efisien dan mampu berkembang mandiri dan dapat membuka lapangan kerja baru.

Dua faktor yang mempengaruhi pengambilan keputusan konsumen dalam melakukan pem-belian yaitu faktor internal dan faktor eksternal (Asseal, 1992). Faktor eksternal terdiri dari faktor lingkungan dan strategi bauran pemasaran. Faktor lingkungan terdiri dari faktor budaya, referensi dan kelas sosial. Strategi bauran pemasaran terdiri dari produk, harga, promosi, dan distribusi. Faktor internal terdiri dari faktor gagasan dan karakteristik konsumen. Faktor internal dan eksternal dalam interaksinya dapat mempengaruhi perilaku kon-sumen baik secara individual maupun secara bersama-sama.

Konsumen melakukan pembelian tidak terlepas dari karakteristik produk baik mengenai penampilan, gaya, mutu dan harga dari produk tersebut. Penetapan harga oleh penjual akan ber-pengaruh terhadap perilaku pembelian konsumen, sebab harga yang dapat dijangkau oleh konsumen akan cenderung membuat konsumen melakukan pembelian terhadap produk tersebut. Karakteristik penjualan teri krispi akan mempengaruhi keputusan membeli. Konsumen akan menilai mengenai penjual, baik mengenai pelayanan, mudahnya memperoleh produk dan sikap ramah dari penjual (Tedjakusuma et al., 2001).

Penelitian tentang pola konsumsi bahan makan di Indonesia dilakukan oleh I Wayan Rusastra, yang bermaksud menggambarkan pola konsumsi bahan makan di Indonesia khususnya produk pangan ternak dan ikan,yang dikomposisikan dengan bahan makanan pokok beras. Dari hasil penelitiannya menunjukkan rendahnya konsumsi produk pangan ternak dibandingkan dengan konsumsi ikan dan beras, baik di pedesaan maupun dikota.(Kusdiyanto,2014)

Penjual teri krispi harus memahami keinginan konsumen dengan cara mempelajari perilaku konsumen agar konsumen bersedia membeli teri krispinya. Pemahaman perilaku konsumen yang baik dan tepat diharapkan akan mengembangkan kegiatan pemasarannya. 
Penjual teri krispi perlu mengenal konsumen, sasaran dan model keputusan yang dilakukan oleh konsumen, sehingga penjual teri krispi mengetahui motif konsumen dalam menilai teri krispi yang sesuai dengan hati nuraninya. Analisis faktor digunakan untuk menentukan urutan faktor yang dipertimbangkan oleh konsumen dalam membeli teri krispi di Pamekasan, sehingga perlu dilakukan penelitian agar penjual teri krispi dapat mempertahankan eksistensinya.

\section{METODE PENELITIAN}

Pada penelitian ini dilakukan dengan metode survei di Kabupaten Pamekasan dengan pertimbangan bahwa Kabupaten Pamekasan dikenal sebagai Kota penghasil teri. Pengambilan data dilaksanakan pada bulan Oktober 2016 di lima lokasi terbesar yang diambil secara purposive sampling yaitu di lima Toko Camilan Madura yaitu Toko Camilan di Niaga, Depot Hijau,Toko Mustika, Toko Camilan Panglegur, dan Toko Putih Jumlah sampel sebanyak 50 responden yang diambil secara Incidental Sampling. Pengumpulan data primer dengan melakukan tanya jawab dengan responden berdasarkan kuesioner yang telah dipersiapkan. Analisis statistik deskriptif digunakan untuk mendiskripsikan karakteristik responden yang diteliti serta distribusi item dari tiap variabel dalam angka persentase. Analisis faktor digunakan untuk Perilaku Konsumen dalam Pembelian Teri krispi di Pamekasan menentukan urutan faktor yang dipertimbangkan oleh konsumen dalam membeli teri krispi. Jenis data yang digunakan analisis faktor adalah data ordinal dan skala pengukuran yang digunakan adalah skala Likert.

\section{HASIL DAN PEMBAHASAN}

\section{Gambaran umum responden}

Hasil survei menunjukkan bahwa usia konsumen yang mendominasi adalah kelompok usia 36-45 tahun sebanyak 45,11\% dan usia 26-35 tahun sebanyak $15,24 \%$ (Tabel 1). Kelompok usia ini tergolong usia produktif sehingga memerlukan kandungan nutrisi yang cukup bagi tubuh dan perlunya menjaga kesehatan. Konsumen pada dewasa dipengaruhi oleh aktifitas yang ditekuninya, teman-teman, dan kebutuhan mereka. Usia responden diatas 46 tahun lebih sedikit dikarenakan pada usia ini seseorang lebih berhati-hati dalam memilih dan mengkonsumsi makanan.

Hasil survei menunjukkan (Tabel 2) bahwa responden perempuan $(73,55 \%)$ lebih banyak dijumpai dibanding laki-laki 
$(26,45 \%)$ karena perempuan cenderung lebih didominasi kaum perempuan karena untuk membeli karena selain unyuk perempuan mempunyai kecenderungan camilan juga sebagai oleh-oleh untuk lebih senang berbelanja, mudah teman maupun saudara. Hasil penelitian terpengaruh oleh emosi dan menyukai ini sejalan dengan hasil penelitian jajan atau ngemil. Alasan ini yang Hermanianto dan Andayani (2002) yang melatarbelakangi wanita sebagai menjelaskan bahwa pembeli teri krispi konsumen terbesar teri krispi.

Tabel 1. Karakteristik responden berdasarkan usia

\begin{tabular}{cc}
\hline Usia (tahun) & Persentase \\
\hline $16-25$ & 10,12 \\
$26-35$ & 15,24 \\
$36-45$ & 45,11 \\
$46-55$ & 2,15 \\
$56-65$ & 2,02 \\
\hline Jumlah (total) & 100,00 \\
\hline
\end{tabular}

Tabel 2. Karakteristik Responden Berdasarkan Jenis Kelamin

\begin{tabular}{cc}
\hline Jenis kelamin & Persentase \\
\hline Laki-laki (male) & 26,45 \\
Perempuan (female) & 73,55 \\
\hline Jumlah (total) & 100,00
\end{tabular}

Tabel 3. Analisis Faktor Perilaku Konsumen dalam Pembelian Teri Krispi

\begin{tabular}{|c|c|c|c|c|}
\hline Faktor & Variabel & Eigen value & $\begin{array}{l}\text { Loading } \\
\text { factor }\end{array}$ & $\%$ \\
\hline $\begin{array}{l}\text { Persepsi konsumen } \\
\text { (consumer perception) }\end{array}$ & $\begin{array}{l}\text {-Kepercayaan (confidence) } \\
\text {-Produk terkenal (famous products) } \\
\text {-Ukuran produk (size of product) } \\
\text {-Harga (price) }\end{array}$ & 3,672 & $\begin{array}{l}0,429 \\
0,551 \\
0,675 \\
0,717\end{array}$ & 16,69 \\
\hline $\begin{array}{l}\text { Lingkungan } \\
\text { (environment) }\end{array}$ & $\begin{array}{l}\text {-Kebudayaan (culture) } \\
\text {-Kelas sosial (social class) } \\
\text {-Kelompok sosial (social groups) }\end{array}$ & 2,048 & $\begin{array}{l}0,680 \\
0,741 \\
0,729\end{array}$ & 9,31 \\
\hline Referensi (reference) & $\begin{array}{l}\text {-Pengetahuan (knowledge) } \\
\text {-Faktor promosi (promoting factor) }\end{array}$ & & $\begin{array}{l}0,577 \\
0,623\end{array}$ & \\
\hline & & 1,915 & 0,814 & 8,71 \\
\hline $\begin{array}{l}\text { Kepedulian produsen } \\
\text { (concern }\end{array}$ & $\begin{array}{l}\text {-Kenyamanan (convenience) } \\
\text {-Pelayanan produsen (producer service) }\end{array}$ & & $\begin{array}{l}0,486 \\
0,780\end{array}$ & \\
\hline
\end{tabular}




\section{manufacturer)}

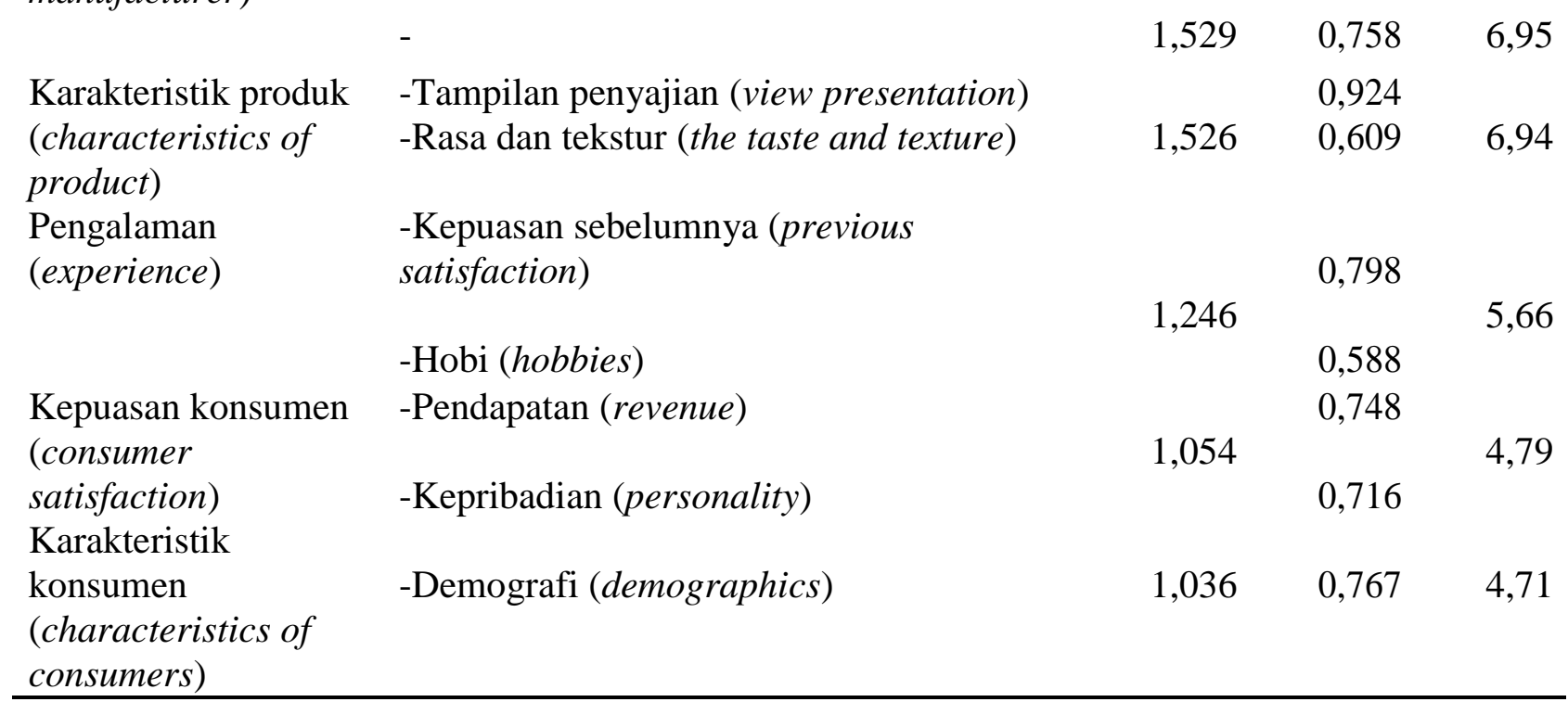

Pembelian oleh konsumen erat hubungannya dengan tingkat pendapatan seseorang dan pengeluaran seseorang. Jika semakin tinggi tingkat pendapatan seseorang maka cenderung semakin tinggi pula pengeluaran yang dilakukan.

Faktor karakteristik konsumen memiliki persentase varian sebesar $4,708 \%$ dan merupakan urutan ketujuh yang dipertimbangkan oleh konsumen karena mempunyai nilai Eigen Value terbesar yaitu 1,036. Variabel demografi sudah pasti memiliki factor loading terbesar karena variabel demografi merupakan variabel satu-satunya yang diwakili faktor karakteristik konsumen yaitu sebesar 0,767 yang artinya bahwa variabel demografi memiliki korelasi yang sangat kuat terhadap faktor karakteristik konsumen.
Demografi konsumen didekati dengan variabel-variabel seperti usia, jenis kelamin, pen-didikan, dan pendapatan. Responden wanita cenderung lebih senang berbelanja, mudah ter-pengaruh oleh emosi, dan menyukai jajan atau makanan camilan.

\section{KESIMPULAN}

Sebagian besar responden yang melakukan pembelian teri krispi adalah perempuan, berstatus ibu rumah tangga, berumur di atas 35 tahun, pendapatan individu yang diperoleh antara Rp. 1.000.000,00 sampai Rp. 2.500.000,00 per bulan dan harga teri krispi rata-rata Rp. 20.000,00 perbungkus dapat dikategorikan terjangkau. Pola mengkonsumi teri krispi bukan sebagai makanan pokok tetapi sebagai kuliner, 
oleh-oleh dan makanan camilan. Delapan faktor yang dipertimbangkan responden secara berurutan adalah harga, rasa,kelas sosial, tampilan penyajian, kepuasan, pendapatan, dan demografi.

\section{DAFTAR PUSTAKA}

Asseal, H. (1992). Consumer Behavior and Marketing Action. New York: PWS-KENT. Publishing Company, Boston

Hermanianto, J. dan R.Y. Andayani. (2002). Studi perilaku konsumen dan identifikasi parameter i bakso sapi berdasarkan preferensi konsumen di wilayah DKI Jakarta. Jurnal Teknologi dan Indutri Pangan 13(1): 1-10.

Kusdiyanto, (2014). Analisis Perilaku Konsumen Terhadap Permintaan Ikan di Kota Surakarta, Prosiding RESEARCH METHODS AND ORGANIZATIONAL STUDIES Hlm. 102-108

Nazarul A.2016. Ikan Teri Nasi. https://nazarulakmal.wordpress.co m/2016/05/18/ikan-teri-nasi/

Parubak, B., A. Thoyib, dan A. Suman.
2004. Faktor faktor yang dipertimbangkan konsumen dalam pembelian kain donggala di Kotamadya Palu. Kumpulan Artikel Seminar Hasil Penelitian. Bidang Kajian Perilaku Konsumen. Program Magister Manajemen. Pascasarjana, Universitas Brawijaya. Pamekasan. Hal. 1-12.

Sudarmiatin. 2009. Model perilaku konsumen dalam perspektif teori dan empiris pada jasa pariwisata. Jurnal Ekonomi Bisnis 14(1): 1-11.

Sulistyawati, E. 2004. Analisis faktor faktor yang mempengaruhi perilaku konsumen dalam keputusan pembelian produk patung kayu pada toko kerajinan di Kecamatan Sukawati, Gianyar, Bali. Kumpulan artikel Seminar Hasil Penelitian. Bidang kajian Perilaku Konsumen. Program Magister Manajemen Universitas Brawijaya Pamekasan. Hal. 67-84.

Tedjakusuma, R., S. Hartini, dan Muryani. 2001. Analisis faktor-faktor yang mempengaruhi perilaku konsumen dalam pembelian air minum mineral di Kotamadya Surabaya. Jurnal Penelitian Dinamika Sosial 2(3): 48-58. 